\title{
The Role of Snowpack, Rainfall, and Reservoirs in Buffering California Against Drought Effects
}

California's vast reservoir system, fed by annual snowand rainfall, plays an important part in providing water to the State's human and wildlife population. There are almost 1,300 reservoirs throughout the State, but only approximately 200 of them are considered storage reservoirs, and many of the larger ones are critical components of the Federal Central Valley Project and California State Water Project. Storage reservoirs, such as the ones shown in figure 1, capture winter precipitation for use in California's dry summer months. In addition to engineered reservoir storage, California also depends on water "stored" in the statewide snowpack, which slowly melts during the course of the summer, to augment the State's water supply.

\section{The Role of Storage Reservoirs}

Of the State's almost 200 storage reservoirs, a dozen majcr reservoirs hold about half of the water stored in California's reservoirs (Dettinger and Anderson, 2015). Each of these majo: reservoirs is multipurpose, and most are operated to meet environmental mandates, including providing flows and coldwater storage for anadromous fish. Of these 12 major reservoirs, 9 either impound storage in, or provide water supply to, the Sacramento River and San Joaquin River watersheds. These reservoirs include Shasta, Oroville, Trinity, New Melones, Don Pedro, McClure (impounded by Exchequer Dam), Pine Flat, Folsom, and Millerton. The other three major reservoirs-San Luis, Castaic, and Perris - are off-stream storage reservoirs built to help optimize the operations of either the Federal Central Valley Project or the California State Water Project. Many of the smaller reservoirs are operated primarily for hydropower and supply millions of megawatts of electricity. These reservoirslarge and small — are all important to keep California thriving. Despite having a cumulative storage capacity of almost 45 million acre-feet, these reservoirs currently hold less than their full capacity for a variety of reasons (fig. 2).

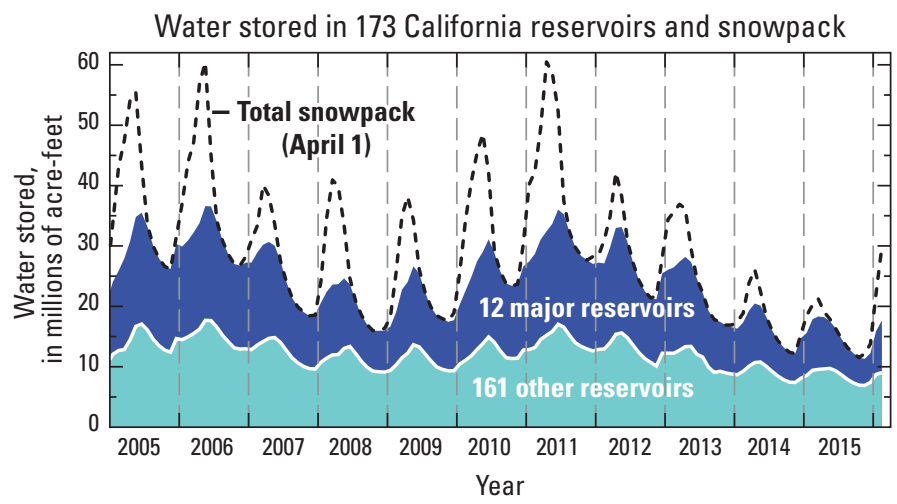

Figure 2. Monthly totals of water stored in 12 major reservoirs, 161 other reservoirs, and (black dashed line) estimated statewidetotal of water stored in snowpack, January 2005 through April 2016. Modified from Dettinger and Anderson, 2015

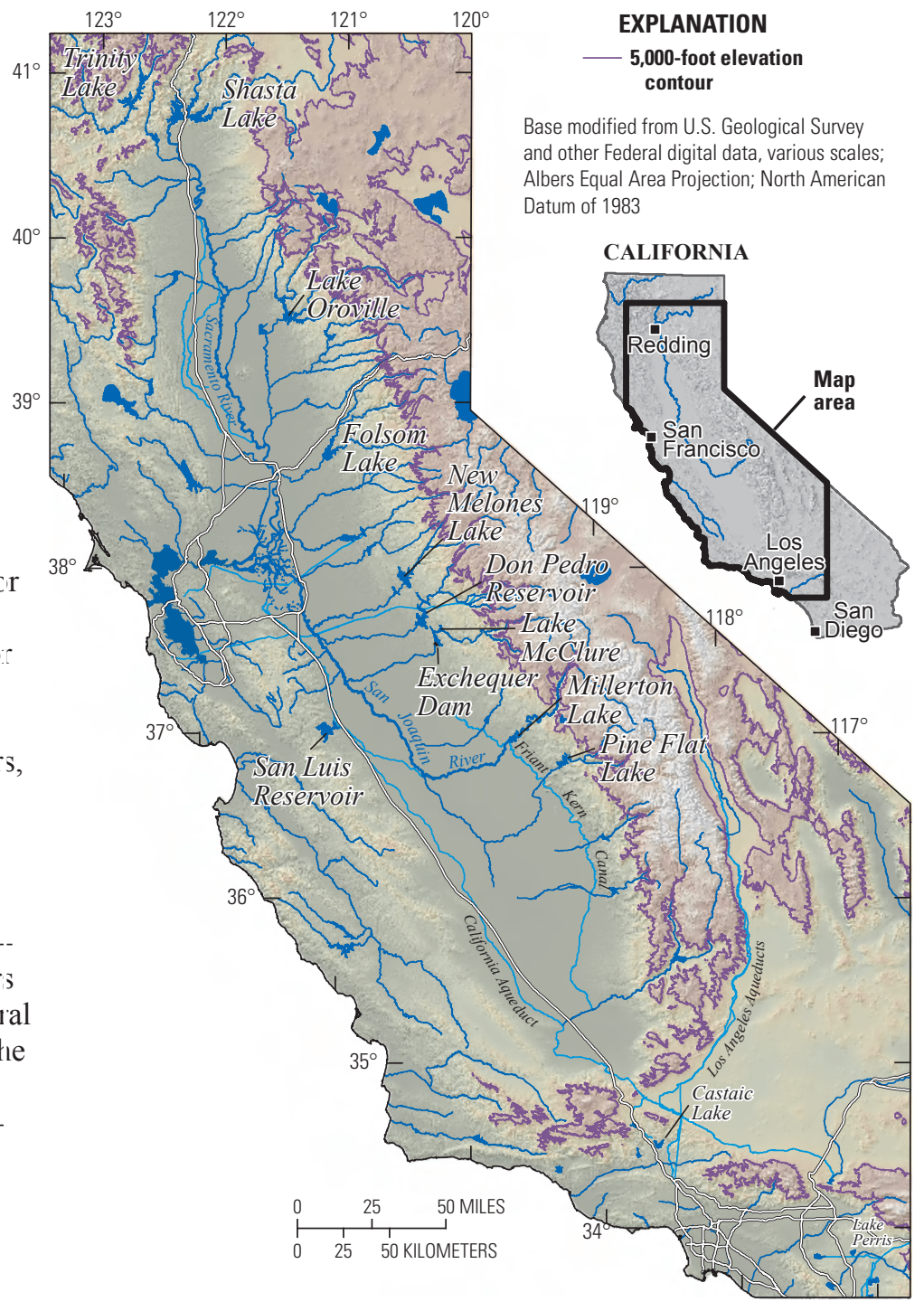

Figure 1. Twelve major California reservoirs.

\section{Snow and Reservoirs}

Snowpack is important to keep California's reservoirs full. Winter and spring snowpack typically melts gradually throughout the year, flowing into and refilling reservoirs. Snowpack accounts for the much of California's water source and storage, because early spring snowpack "contains about 70 percent as much water, on average, as the long-term average combination of the major and 'other' reservoirs" (Dettinger and Anderson, 2015).

A collaboration between U.S. Geological Survey research hydrologist, Michael Dettinger, and California State Climatologist, Michael Anderson, to investigate long-term water storage in California reservoirs showed different roles for the 
two categories of reservoirs. They looked as far back as 1970 to determine how annual snowpack has historically affected the water supply of the 12 major reservoirs and 148 smaller reservoirs. They, then, analyzed the recorded snow-water content to determine the total water in the snowpack for every April 1 since 1970. By examining the correlation between these two sets of data, Dettinger and Anderson concluded the 12 major reservoirs have been operated aggressively to alleviate the effects of drought and flood historically, whereas the 148 smaller reservoirs were not operated in this manner.

Dettinger and Anderson also used this understanding of the historical relationship between snowpack and reservoir usage to investigate how the most recent California drought, for which the governor issued an emergency proclamation on January 17, 2014, has affected reservoir storage. In April 2015, the snow-water content was essentially zero. Because the April snow-water content helps recharge surface-reservoir storage during the spring and summer months, a snow-water deficit causes storage reservoirs - depleted throughout the year - to go without crucial refilling. Dettinger and Anderson determined that reservoir replenishment in winter 2015 was only about 9 percent of normal. Thus, in 2015, California's major reservoirs-which are important tools to manage water supply through drought conditions - did not receive the snowpack runoff necessary to refill them after 3 years of drought. The authors state, "The current challenge to statewide water managers is less the lack of water in the reservoirs and much more the lack of water in snowpack that normally would be expected to melt soon and replenish our reservoirs." Unfortunately, because of the expected consequences of climate change, the lack of snow storage in 2015 could become more the norm than the exception in years to come.

\section{Rain, Soils, and Reservoirs}

Rainfall is another essential water source. It replenishes water in soils, groundwater, streams, lakes, and reservoirs alike. During droughts, dry soils absorb and store a substantial amount of water in the watersheds upstream from reservoirs, reducing the amount of rainfall that flows into and refills reservoirs.

In 2015, USGS scientists Alan Flint and Lorraine Flint analyzed drought conditions for two California watershedsthe Feather and Tuolumne-home to Oroville and Don Pedro Reservoirs, respectively. They examined the soil in the watersheds to estimate the amount of rainfall needed for them to recover from the drought. Although intense rain could generate runoff without correcting the soil-moisture deficit, Flint and Flint determined that a substantial amount of rainfall would first be needed to fill the soil-moisture deficit. While intense rainfall generates runoff to reservoirs, much of the precipitation would amend the soil-moisture deficit before becoming the greatly needed inflow to the reservoirs. Flint and Flint predicted that - considering the soil-moisture deficit and the volume of the reservoirs-large storms, totaling 14.8 inches and 15.9 inches, are needed to alleviate storage-deficit conditions in Oroville and Don Pedro Reservoirs, respectively. These values are an optimistic estimate because they are based on an assumption that all the rain falls at once with no draingage or evapotranspiration. These storms are sizable, considering the average annual precipitation of the eight-station index (eight monitoring stations in the northern Sierra area) is 50 inches and that of the five-station index (five stations in the San Joaquin area) is 40.8 inches.

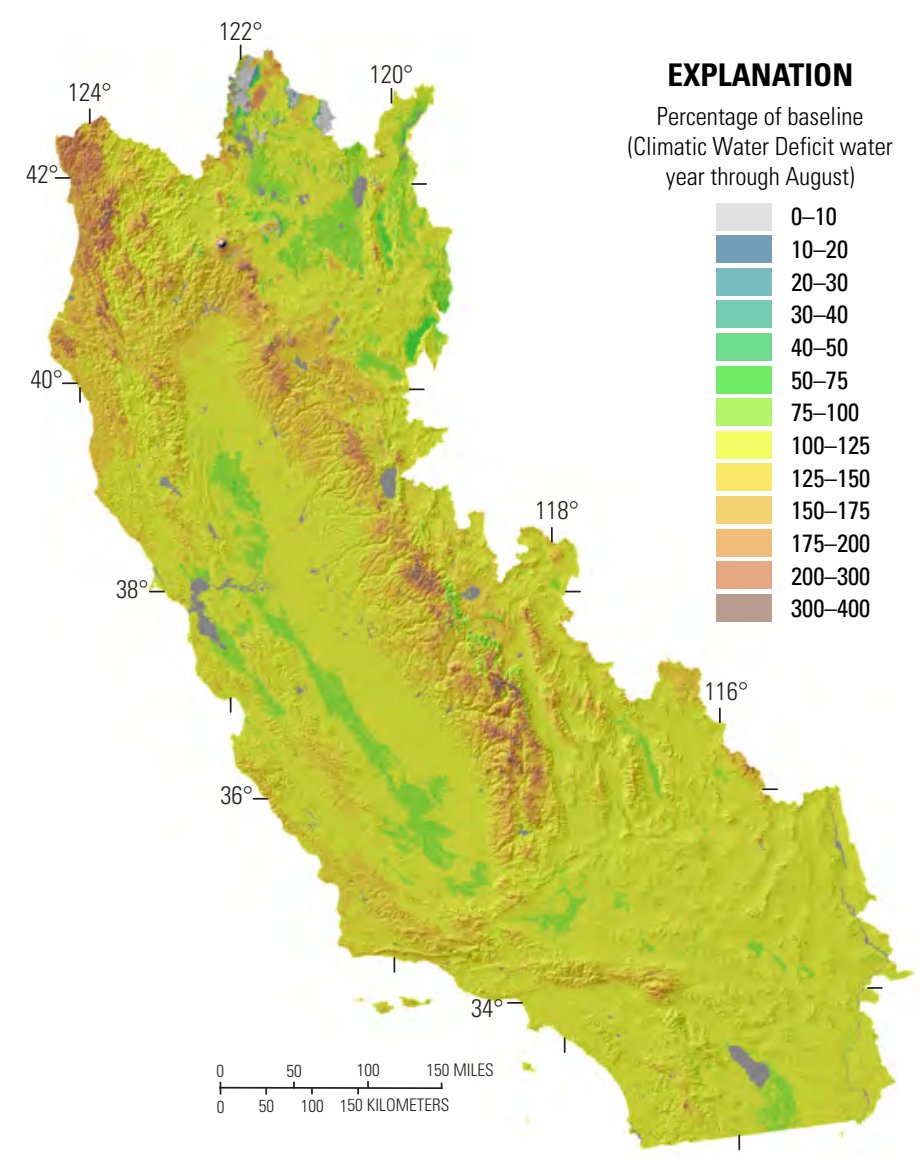

Figure 3. Climatic water deficit (CWD) accumulated through wateryear 2015 as a percentage of the baseline CWD (average year for 1951-1980). Updated from Flint and others, 2013.

One concept scientists use to understand soil-water deficit is the climatic water deficit (CWD). This indicator is calculated as potential evapotranspiration (the amount of water that would be used by plants, if it were available) minus actual evapotranspiration, and it reflects the loss of water from the soil as well as the soil-water deficit generated during the year from vegetation demands. Water-year 2015 resulted in between 125 and 400 percent greater CWD than baseline for about 90 percent of the State (fig. 3). High CWD indicates high landscape stress, which led to forest die-off and extreme wildfire conditions in California during 2015, as well as poor forage conditions on rangelands.

The studies by Dettinger and Anderson and Flint and Flint are telling with regard to the effects both snow and rain have on our vital California reservoirs. Studies such as these can help managers plan for new water-storage options and to manage existing reservoirs optimally.

\section{References}

Dettinger, M.D., and Anderson, M. L., 2015, Storage in California's reservoirs and snowpack in this time of drought: San Francisco Estuary and Watershed Science, v. 13, no. 2,jmie_sfews_27912, http://escholarship.org/uc/ item $/ 8 m 26 d 692$

Flint, Lorraine, Flint, Alan, Thorne, James, and Boynton, Ryan, 2013, Fine-scale hydrologic modeling for regional landscape applications: the California Basin Characterization Model development and performance: Ecological Processes, v. 2, p. 25, http://dx.doi.org/10.1186/2192-1709-2-25 